\title{
SWELLING AND STRUCTURE OF VANADIUM-BASE ALLOYS IRRADIATED IN THE DYNAMIC FELIUM CHARGING EXPERIMENT*
}

\author{
by
}

H. M. Chung, B. A. Loomis, and D. L. Smith

Argonne National Laboratory

Argonne, IL 60439, U.S.A.

\section{DISCLAIMER}

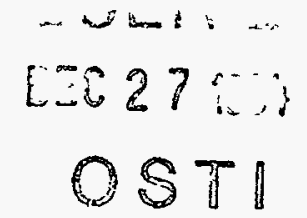

This report was prepared as an account of work sponsored by an agency of the United States Government. Neither the United States Government nor any agency thereof, nor any of their employees, makes any warranty, express or implied, or assumes any legal liability or responsibility for the accuracy, completeness, or usefulness of any information, apparatus, product, or process disclosed, or represents that its use would not infringe privately owned rights. Reference herein to any specific commercial product, process, or service by trade name, trademark, manufacturer, or otherwise does not necessarily constitute or imply its endorsement, recommendation, or favoring by the United States Government or any agency thereof. The views and opinions of authors expressed herein do not necessarily state or reflect those of the United States Government or any agency thereof.

Presented at the 17th Symposium on Effects of Radiation on Materials, June 20-23, 1994. Sun Valley, Idaho.

*Work supported by the U.S. Department of Energy, Office of Fusion Energy, under Contract W-31-109-Eng-38. 


\section{DISCLAIMER}

Portions of this document may be illegible in electronic image products. Images are produced from the best available original document. 


\title{
SWELLING AND STRUCTURE OF VANADIUM-BASE ALLOYS IRRADIATED IN THIS DYNAMIC HELTUM CHARGING EXPERMMENT*
}

\author{
H. M. Chung, B. A. Loomis, and D. L. Smith \\ Argonne National Laboratory \\ Argonne, IL 60439, U.S.A.
}

\begin{abstract}
Combined effects of dynamically charged helium and neutron damage on density change, vold distribution, and microstructural evolution of $\mathrm{V}-4 \mathrm{Cr}-4 \mathrm{TI}$ alloy have been determined after irradiation to $18-31 \mathrm{dpa}$ at $425-600^{\circ} \mathrm{C}$ in the Dynamic Helium Charging Experiment (DHCE), and the results were compared with those from a non-DHCE in which helium generation was negligible. For specimens irradiated to $\approx 18-31$ dpa at $500-$ $600^{\circ} \mathrm{C}$ with a helium generation rate of $0.4-4.2$ appm He/dpa, only a few helium bubbles were observed at the interface of grain matrices and some of the Ti(O,N,C) precipitates, and no microvolds or helum bubbles were observed either in grain matrices or near grain boundaries. Under these conditions, dynamically produced helium atoms seem to be trapped in the grain matrix without significant bubble nucleation or growth, and in accordance with this, density changes from DHCE and non-DHCE (negligible helium generation) were similar for comparable fluence and irradiation temperature. Only for specimens irradiated to $\approx 31 \mathrm{dpa}$ at $425^{\circ} \mathrm{C}$, when helium was generated at a rate of $0.4-0.8$ appm helium/dpa, were diffuse helium bubbles observed in limited regions of grain matrices and near $\approx 15 \%$ of the grain boundaries in densitles significantly lower than those in the extensive coalescences of helium bubbles typical of other alloys irradiated in tritiumtrick experiments. Density changes of specimens irradiated at $425^{\circ} \mathrm{C}$ in the DHCE were significantly higher than those from non-DHCE irradiation. Microstructural evolution in V$4 \mathrm{Cr}-4 \mathrm{Ti}$ was similar for DHCE and non-DHCE except for helium bubble number density and distribution. As in non-DHCE, the irradiation-induced precipitation of ultrafine $\mathrm{Ti}_{5} \mathrm{Si}_{3}$ was observed for $\mathrm{DHCE}$ at $>500^{\circ} \mathrm{C}$ but not at $425^{\circ} \mathrm{C}$.
\end{abstract}

Key words: vanadium-base alloy, helium, neutron displacement damage. density change, void swelling, fusion reactor first wall

Recent attention in the development of vanadium-base alloys for application in fusion reactor first wall and blanket structure has focused on $\mathrm{V}-4 \mathrm{Cr}-4 \mathrm{Ti}$, an alloy reported to exhibit an excellent combination of mechanical and physical properties before and after irradiation [1-6]. One of the unresolved issues in the performance of the alloy, however, has been the effect of fusion-relevant simultaneous generation of helium and neutron damage (at a ratio of 4-5 appm helium/displacement per atom [dpa]) on density change and void swelling. Hellum effects determined for other vanadium-base alloys by means of less fusion-relevant simulation approaches, such as tritium-trick [7-13], cyclotroninjection [14-18], and boron-doping [18-21] techniques, have been inconsistent with regard to concentration of helium bubbles on grain boundaries and the concomitant propensity for intergranular fracture. In the unique Dynamic Helium Charging Experiment

"Work supported by the U.S. Department of Energy, Office of Fusion Energy, under Contract W-31-109-Eng-38. 
(DHCE), the fusion-relevant helium-to-dpa ratio is simulated realistically by utilizing transmutation of controlled amounts of ${ }^{6} \mathrm{Li}$ and a predetermined amount of tritium-doped mother alloy immersed in ${ }^{6} \mathrm{Li}+{ }^{7} \mathrm{Li}$ [22-24]. This report describes results of microstructural characterization and density measurement primarily of $\mathrm{V}-4 \mathrm{Cr}-4 \mathrm{Ti}$ alloy specimens irradiated to $18-31 \mathrm{dpa}$ at $425-600^{\circ} \mathrm{C}$ in the DHCE.

\section{MATERIALS AND PROCEDURES}

The elemental composition of the $\mathrm{V}-4 \mathrm{Cr}-4 \mathrm{Ti}$ alloy (ANL Identification BL-47), determined prior to irradiation, is given in Table 1. Postirradiation examination of other alloys listed in Table 1 (i.e., V-5TI, V-3Ti-1Si, and V-8Cr-6Ti) was limited, and unless pointed out specifically, all results reported in this study refer to $\mathrm{V}-4 \mathrm{Cr}-4 \mathrm{Ti}$. Fabrication procedures of the alloy ingots and annealed plates and sheets have been reported elsewhere [25]. TEM disks, punched from 0.3-mm-thick cold-worked sheets to investigate density change, void swelling behavior, and microstructural characteristics, were annealed at $1050^{\circ} \mathrm{C}$ in an ion-pumped high-vacuum system. The annealed material was $\approx 95 \%$ recrystallized and exhibited an average grain size of $\approx 14 \mu \mathrm{m}$. Phase structures of the alloy, characterized before and after irradiation in a nonDHCE (negligible helium generation), have been described in detail elsewhere [4]. The only secondary phase present in the as-annealed specimens was $T(O, N, C)$, which is normally observed in titanium-containing vanadium alloys with $\mathrm{O}+\mathrm{N}+\mathrm{C}>400 \mathrm{wppm}[26]$.

Table 1. Chemical composition of vanadium-base alloys

\begin{tabular}{ccccccccccc}
\hline & $\begin{array}{c}\text { Nominal } \\
\text { Composition } \\
\text { ANL ID }\end{array}$ & \multicolumn{10}{c}{\begin{tabular}{c} 
Imp $\%$ ) \\
\cline { 3 - 10 }
\end{tabular}} & $\mathrm{O}$ & $\mathrm{N}$ & $\mathrm{C}$ & $\mathrm{Si}$ & $\mathrm{S}$ & $\mathrm{P}$ & $\mathrm{Nb}$ & Mo \\
\hline BL-47 & V-4.1Cr-4.3Ti & 350 & 220 & 200 & 870 & 20 & $<40$ & $<100$ & $<100$ \\
BL-46 & V-4.6Ti & 305 & 53 & 85 & 160 & 10 & $<100$ & $<100$ & - \\
BL-45 & V-2.5Ti-1.0Si & 345 & 125 & 90 & 9900 & 30 & - & 200 & 140 \\
BL-49 & V-7.9Cr-5.7TI & 400 & 150 & 127 & 360 & 20 & - & $<100$ & 170 \\
\hline
\end{tabular}

The alloy specimens were irradiated in the Fast Flux Test Facility (FFTF), a fast reactor located in Richland, Washington, at 420,520 , and $600^{\circ} \mathrm{C}$ to neutron fluences $(\mathrm{E}>$ $0.1 \mathrm{MeV})$ ranging from $3.7 \times 10^{22} \mathrm{n} / \mathrm{cm}^{2} \Leftrightarrow 18$ displacements per atom, or dpa) to $6.4 \mathrm{x}$ $10^{23} \mathrm{n} / \mathrm{cm}^{2}(\approx 31 \mathrm{dpa})$. Helium in the alloy specimens was produced by utilizing transmutation of controlled amounts of ${ }^{6} \mathrm{Li}$ and a predetermined amount of tritium-doped 
vanadium mother alloy immersed in $6 \mathrm{Li}+{ }^{7} \mathrm{Li}$ [22-24]. Table 2 summarizes the irradiation temperature, weight of the mother alloy, fraction of ${ }^{6} \mathrm{Li}$, and tritium and lithium inventory charged in each of the seven DHCE capsules before irradiation. Table 3 summarizes the actual postirradiation parameters determined from tensile and disk specimens of the V$4 \mathrm{Cr}-4 \mathrm{Tl}$ alloy, i.e., fast neutron fluence, dose, and helium and tritium content measured shortly after the postirradiation tests. Helium and tritium were determined by mass spectrometry at Rockwell International Inc., Canoga Park, California.

Table 2. Summary of capsule-loading parameters of the dynamic helium charging experiment.

\begin{tabular}{|c|c|c|c|c|c|c|c|}
\hline \multirow{2}{*}{$\begin{array}{c}\text { Capsule } \\
\text { ID No. }\end{array}$} & \multirow{2}{*}{$\begin{array}{c}\text { Irradiation } \\
\text { Temp. } \\
\left({ }^{\circ} \mathrm{C}\right) \\
\end{array}$} & \multicolumn{3}{|c|}{ Total Weight (g) } & \multirow{2}{*}{$\begin{array}{c}\text { Fraction } \\
\text { of } 6_{L 1} \\
(\%) \\
\end{array}$} & \multicolumn{2}{|c|}{$\begin{array}{l}\text { Initial Tritium } \\
\text { Chargeda }^{2}\end{array}$} \\
\hline & & Vanadium $^{a}$ & Specimen $\mathrm{b}$ & Lithium & & (Ci) & (mmol) \\
\hline 4D1 & 425 & 1.5468 & 5.86 & 0.765 & 5.0 & 99 & 1.70 \\
\hline $4 \mathrm{D} 2$ & 425 & 1.5536 & 5.38 & 0.765 & 4.5 & 70 & 1.20 \\
\hline $5 \mathrm{E} 2$ & 425 & 1.5657 & 5.38 & 0.670 & 1.0 & 26 & 0.45 \\
\hline $5 D_{1}$ & 500 & 1.5727 & 5.77 & 0.938 & 6.5 & 73.5 & 1.26 \\
\hline $5 \mathrm{E} 1$ & 500 & 1.5651 & 5.82 & 0.952 & 1.0 & 57 & 0.98 \\
\hline $5 \mathrm{Cl}$ & 600 & 1.5656 & 5.82 & 0.808 & 8.0 & 16.4 & 0.28 \\
\hline $5 \mathrm{C} 2$ & 600 & 1.5466 & 5.95 & 0.955 & 8.0 & 18 & 0.31 \\
\hline
\end{tabular}

a Letter from C. E. Johnson to K. Pearce, Aprll 23, $1991 ; 1 \mathrm{mmol}=58.3 \mathrm{Cl}$.

$b$ Excluding tritlum-charged mother alloy.

The retrieved TEM specimens, which contained helium, tritium, and neutron displacement damage, were cleaned ultrasonically in alcohol prior to density measurement and microstructural analysis. Most of the examined TEM disks were not degassed at $400^{\circ} \mathrm{C}$ for $1 \mathrm{~h}$, a customary procedure to expel tritium and hydrogen from Charpy-impact and tensile specimens. Several TEM disks were examined after degassing, but none indicated any appreciable difference in void or helium bubble distribution and microstructure from undegassed specimens that should contain tritium and hydrogen in addition to helium. The irradiated specimens were jet-thinned for TEM in a solution of $15 \%$ sulfuric acid-72\% methanol-13\% butyl cellosolve maintained at $-5^{\circ} \mathrm{C}$. TEM was conducted with a JEOL $100 \mathrm{CX}-\mathrm{II}$ scanning transmission electron microscope operating at $100 \mathrm{keV}$ or with a Philips CM-30 analytical electron microscope operating at $200 \mathrm{keV}$. Density change was determined from specimen weights measured in air and in researchgrade $\mathrm{CCl}_{4}$. 
Table 3. Summary of irradiation parameters of dynamic helium charging experiment and helium and tritium content of $V-4 C r-4 T H$ specimens

\begin{tabular}{|c|c|c|c|c|c|c|c|}
\hline $\begin{array}{l}\text { Capsule } \\
\text { ID No. }\end{array}$ & $\begin{array}{l}\text { Irradiation } \\
\text { Temp. } \\
\left({ }^{\circ} \mathrm{C}\right)\end{array}$ & $\begin{array}{c}\text { Fluence } \\
(E>0.1 \mathrm{MeV}) \\
\left(10^{22} \mathrm{n} \mathrm{cm}^{-2}\right.\end{array}$ & $\begin{array}{c}\text { Total } \\
\text { Damage } \\
\text { (dpa) }\end{array}$ & $\begin{array}{l}\text { Calculated Hellum } \\
\text { (appm)-to-dpa } \\
\text { Ratio at EOI } \\
\left.\text { (Assumed } \mathrm{k}_{\mathrm{a}} \text { or } \mathrm{k}_{\mathrm{w}}\right)^{\mathrm{c}} \\
\mathrm{k}_{\mathrm{a}}=0.073\left(\mathrm{k}_{\mathrm{w}}=0.01\right)\end{array}$ & $\begin{array}{l}\text { Measured } \\
\text { Helium } \\
\text { Content } \\
\text { (appm) }\end{array}$ & $\begin{array}{l}\text { Actual } \\
\text { Helium-to- } \\
\text { dpa Ratio } \\
\text { (appm/dpa) }\end{array}$ & $\begin{array}{c}\text { Measured } \\
\text { Tritium } \\
\text { Contente } \\
\text { (appm) }\end{array}$ \\
\hline 4D1 & 425 & 6.4 & 31 & 3.8 & $11.2-13.3$ & 0.39 & 27 \\
\hline $4 \mathrm{D} 2$ & 425 & 6.4 & 31 & 2.8 & $22.4-22.7$ & 0.73 & 39 \\
\hline $5 \mathrm{E} 2$ & 425 & 3.7 & 18 & 2.1 & $3.3-3.7$ & 0.11 & 2 \\
\hline 5Dl & 500 & 3.7 & 18 & 4.4 & $14.8-15.0$ & 0.83 & 4.5 \\
\hline $5 \mathrm{E} 1$ & 500 & 3.7 & 18 & 3.1 & $6.4-6.5$ & 0.36 & 1.7 \\
\hline $5 \mathrm{Cl}$ & 600 & 3.7 & 18 & 1.1 & $8.4-11.0$ & 0.54 & 20 \\
\hline $5 \mathrm{C} 2$ & 600 & 3.7 & 18 & 1.1 & $74.9-75.3$ & 4.17 & 63 \\
\hline
\end{tabular}

a L. R. Greenwood "Revised Calculations for the DHCE," April 30, 1993.

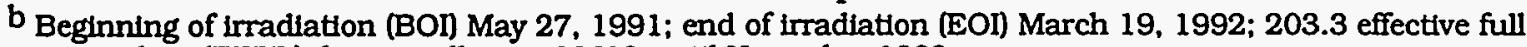
power days (EFPD), hot standby at $=220^{\circ} \mathrm{C}$ until November 1992.

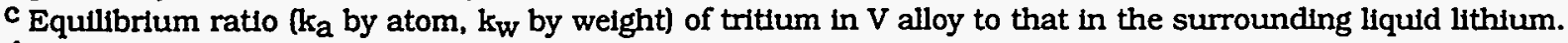

d Measured June 1994.

e Measured August 1994.

\section{MICROSTRUCTURE AND HELIUM BUBBLE DISTRIBUTION}

Microstructural characteristics of the DHCE specimens irradiated to $\approx 18 \mathrm{dpa}$ at $600^{\circ} \mathrm{C}$ in a low-tritium capsule (Capsule $5 \mathrm{C} 1$, helium generation rate of $0.54 \mathrm{He} / \mathrm{dpa}$ ) are shown in Fig. 1. Voids in these specimens were absent, except for a few helium bubbles at interfaces between the grain matrix and a limited number of $\mathrm{Ti}(\mathrm{O}, \mathrm{N}, \mathrm{C})$ precipitates (Fig. 1A). In Fig. 1A, eight $\approx 30-\mathrm{nm}$ helium bubbles are visible near 4 of the $25 \mathrm{Ti}(\mathrm{O}, \mathrm{N}, \mathrm{C})$ precipitates present. In the bright-field image in Fig. 1B are visible dense dislocation loops, short dislocations, ultrafine $\mathrm{Ti}_{5} \mathrm{Si}_{3}$ precipitates, and blocky $\mathrm{Ti}(\mathrm{O}, \mathrm{N}, \mathrm{C})$ precipitates. No microvolds are visible either near the grain boundary or in the grain matrix shown in Fig. 1B. These microstructural characteristics are similar to those observed in non-DHCE specimens irradiated under similar conditions $\left(\approx 28 \mathrm{dpa}, 600^{\circ} \mathrm{C}\right.$, Fig. $\left.1 \mathrm{D}\right)$. The morphologies of $\mathrm{Ti}_{5} \mathrm{Si}_{3}$ precipitates, obtained from specimens irradiated in the DHCE $\approx 18$ $\left.\mathrm{dpa}, 600^{\circ} \mathrm{C}\right)$ and non-DHCE $\left(\approx 28 \mathrm{dpa}, 600^{\circ} \mathrm{C}\right)$ and shown in the dark-field images of Fig. 1C and $1 \mathrm{E}$, respectively, are also similar.

Specimens irradiated to $18 \mathrm{dpa}$ at $500-600^{\circ} \mathrm{C}$ in the other three capsules (Capsule $5 \mathrm{D} 1$, hellum generation rate of $0.83 \mathrm{He} / \mathrm{dpa}$; $5 \mathrm{E} 1,0.36 \mathrm{He} / \mathrm{dpa}$; and $5 \mathrm{C} 2,4.2 \mathrm{He} / \mathrm{dpa}$ ) exhibited microstructural characteristics essentially similar to those of specimens from 
Capsule $5 \mathrm{Cl}$ (Figs. $1 \mathrm{~A}-1 \mathrm{C}$ ), i.e.. no helium bubbles either in the grain matrix or on grain boundaries, a few helium bubbles on the interface between the grain matrix and a limited number of $\mathrm{Ti}(\mathrm{O}, \mathrm{N}, \mathrm{C})$ precipitates, and ultrafine $\mathrm{Ti}_{5} \mathrm{Si}_{3}$ precipitates in high density. For irradiations at $500-600^{\circ} \mathrm{C}$. virtually all of the dynamically produced helium atoms seem to have been trapped in the grain matrix without significant bubble nucleation or growth.
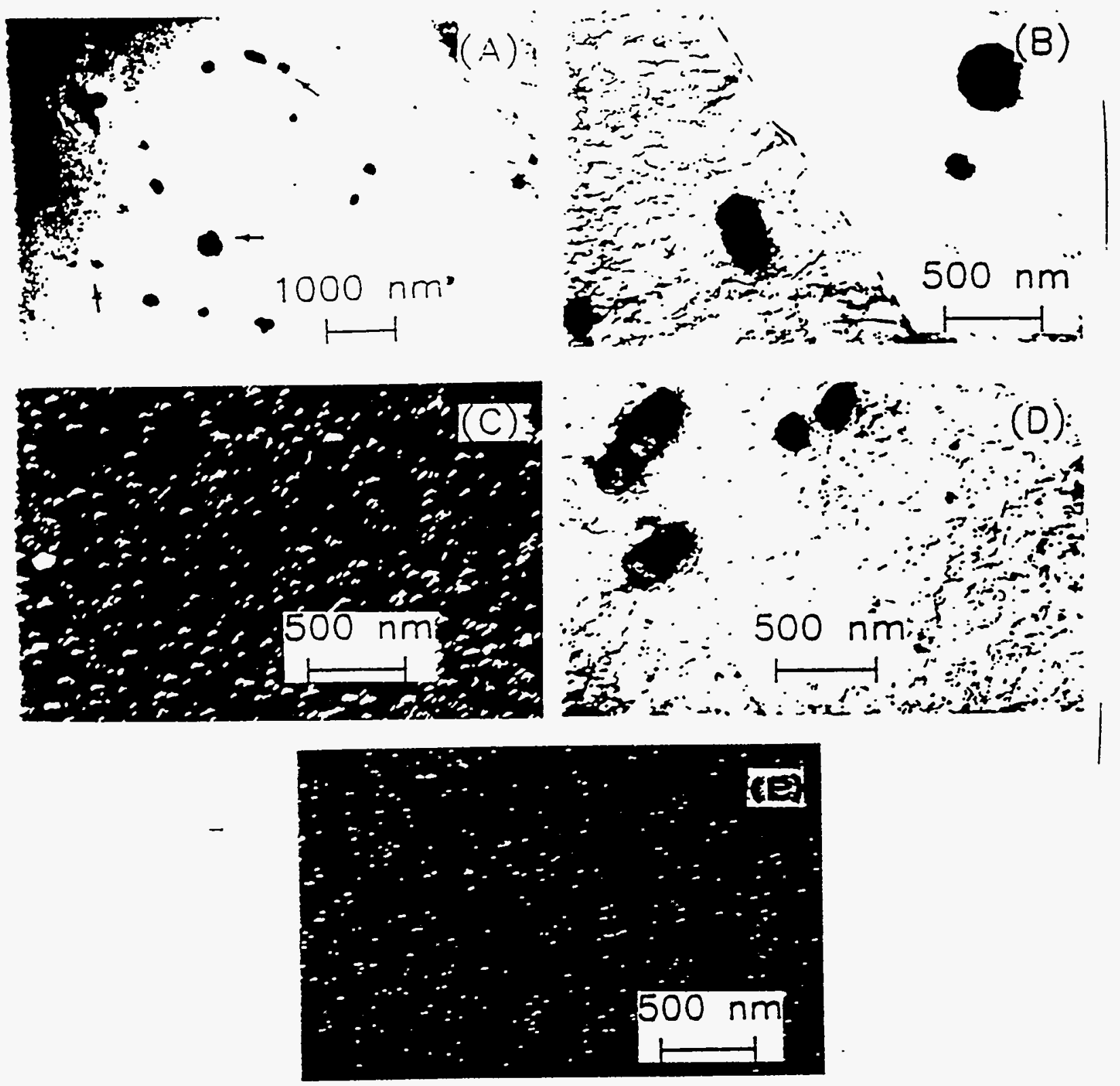

Figure 1. Microstructure of $\mathrm{V}-4 \mathrm{Cr}-4 \mathrm{Ti}$ irradiated at $600^{\circ} \mathrm{C}$ to $\approx 18 \mathrm{dpa}$ in $\mathrm{DHCE}$ (Capsule 5C1): (A) voids near Ti(O,N,C); (B) dislocations, dislocation loops, and Ti5Si3; (C) dark-field image of Ti5Si3. (D) and (E) are similar to (B) and $(C)$, respectively, but from specimens irradiated at $600^{\circ} \mathrm{C}$ to $\approx 28 \mathrm{dpa}$ in a non-DHCE. 
For DHCE specimens irradiated to 31 dpa at $425^{\circ} \mathrm{C}$ in high-tritium capsules $4 \mathrm{Dl}$ (helium generation rate $=0.4 \mathrm{He} / \mathrm{dpa}$ ) and $4 \mathrm{D} 2$ (helium generation rate of $\approx 0.73 \mathrm{He} / \mathrm{dpa}$ ), helium bubbles $(\approx 5 \mathrm{~nm}$ in diameter) were observed in the grain matrix as well as on $\approx 15 \%$ of the grain boundaries. This is shown in Fig. 2. Helium bubbles observed near grain boundaries in these specimens were characterized by diffuse bubbles (Fig. 2A) in a number density significantly lower than that of the compact coalescences of helium bubbles observed in other alloys irradiated in tritium-trick experiments [7-12]; discontinuous $(\approx 15 \%$ of grain boundaries), in contrast to continuous $(\approx 100 \%$ of grain boundaries), colaescence observed in tritium-trick experiments [7-12]; and more or less similar bubble distribution in the grain matrix and near grain boundaries, in contrast to virtual concentration of all helium bubbles on grain boundaries in tritium-trick experiments. The latter observation seems to indicate that most of the helium atoms produced dynamically at $425^{\circ} \mathrm{C}$ were trapped in the grain matrix, preventing extensive formation of a continuous coalescence of helium bubbles on grain boundaries.
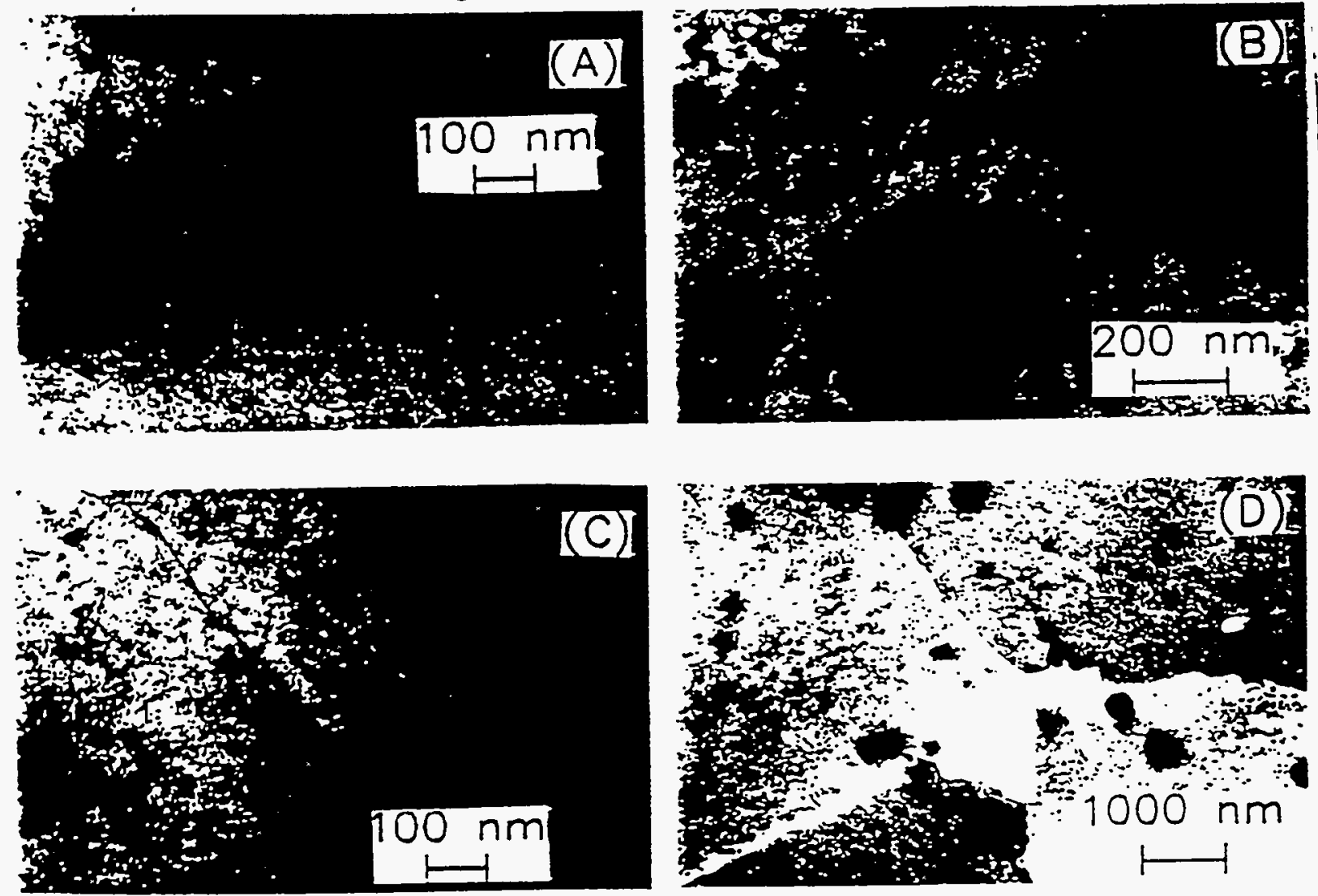

Figure 2. Microstructure of $V-4 C r-4 T i$ irradiated at $425^{\circ} \mathrm{C}$ to $\approx 31 \mathrm{dpa}$ in $D H C E$ (Capsules 4D2 and 4D1): (A) voids near grain boundary; (B) void shells surrounding Ti(O,N,C); (C) similar void distributions in grain matrix and near grain boundaries; and (D) low magnification of grains and $T i(O, N, C)$. 
Some of the specimens irradiated to $31 \mathrm{dpa}$ at $425^{\circ} \mathrm{C}$ were also characterized by extremely thin $(\approx 5 \mathrm{~nm})$ shells of voids that surround some of the $T(1 O, N, C)$ precipitates. An example of the helium shells is shown in Fig. 2B. The shells are believed to be composed of continuous helium bubbles similar to those shown in Fig. 1A. These observations clearly show that helium atoms are effectively trapped at the interface of the grain matrix and $\mathrm{TI}(\mathrm{O}, \mathrm{N}, \mathrm{C})$ precipitates. Helium bubbles were negligible in grain matrix, on grain boundaries, or at the interface of the grain matrix and Ti(O,N,C) precipitates in specimens irradiated to $18 \mathrm{dpa}$ at $425^{\circ} \mathrm{C}$ in Capsule $5 \mathrm{E} 2$ (helium generation rate $\approx 0.11$ $\mathrm{He} / \mathrm{dpa}$.

As in non-DHCEs [4], $\mathrm{Ti}_{5} \mathrm{Si}_{3}$ did not precipitate during irradiation at $425^{\circ} \mathrm{C}$ in the DHCEs. If $\mathrm{Ti}_{5} \mathrm{Si}_{3}$ precipitation was indeed significant for $425^{\circ} \mathrm{C}$ irradiation, void swelling at that temperature would have been suppressed significantly, as in other alloys irradiated at $420^{\circ} \mathrm{C}$ in non-DHCEs [27].

\section{DENSITY CHANGE}

Results of density measurements for specimens irradiated at 600 (18 dpa in Capsule 5C1) and $425^{\circ} \mathrm{C}$ (18 dpa in Capsule 5E2, $31 \mathrm{dpa}$ in Capsules $4 \mathrm{D} 1$ and 4D2) are given in Figs. $3 A$ and $3 B$, respectively. The helium content of the DHCE specimens is also given in the figure (see Table 1). For comparison, density changes determined for similar irradiation conditions in non-DHCEs [3], are also shown in the figures.

Density changes measured for the non-DHCE and DHCE specimens irradiated at $600^{\circ} \mathrm{C}$ in the low-tritium capsule $(5 \mathrm{Cl}$, helium generation rate $\approx 0.54 \mathrm{appm} \mathrm{He} / \mathrm{dpa}$ ) were low $(<0.6 \%)$. The small density change seems to be consistent with the negligible number density of voids or helium bubbles (Fig. 1). However, density changes measured for the DHCE specimens irradiated at $425^{\circ} \mathrm{C}$ in the high-tritium capsules (4D1, helium generation rate $\approx 0.4 \mathrm{He} / \mathrm{dpa}$ and $4 \mathrm{D} 2$, helium generation rate $\approx 0.73 \mathrm{He} / \mathrm{dpa}$ ) were significantly higher than those of the non-DHCE specimens. The relatively large density changes measured for these specimens seem also to be consistent with the relatively higher number density of helium bubbles (Fig. 2).

Density changes measured for disk specimens of V-5Ti, V-3Ti-1Si, and V-8Cr-6Ti, irradiated to $\approx 18 \mathrm{dpa}$ at $425^{\circ} \mathrm{C}$ in a $\mathrm{DHCE}$ in Capsule $5 \mathrm{E} 2$, are shown in Fig. 4 . In the 
figure, density changes in the DHCE are compared with those obtained on similar specimens irradiated to $\approx 34 \mathrm{dpa}$ in a non-DHCE. Although the helium content of these alloy specimens was not measured, the actual helium generation rate was expected to be low and similar to that of $\mathrm{V}-4 \mathrm{Cr}-4 \mathrm{Ti}$ (i.e., $0.11 \mathrm{appm} \mathrm{He} / \mathrm{dpa}$ ). Effects of helium on density changes in these alloy specimens were insignificant, probably reflecting the low hellum generation rate.
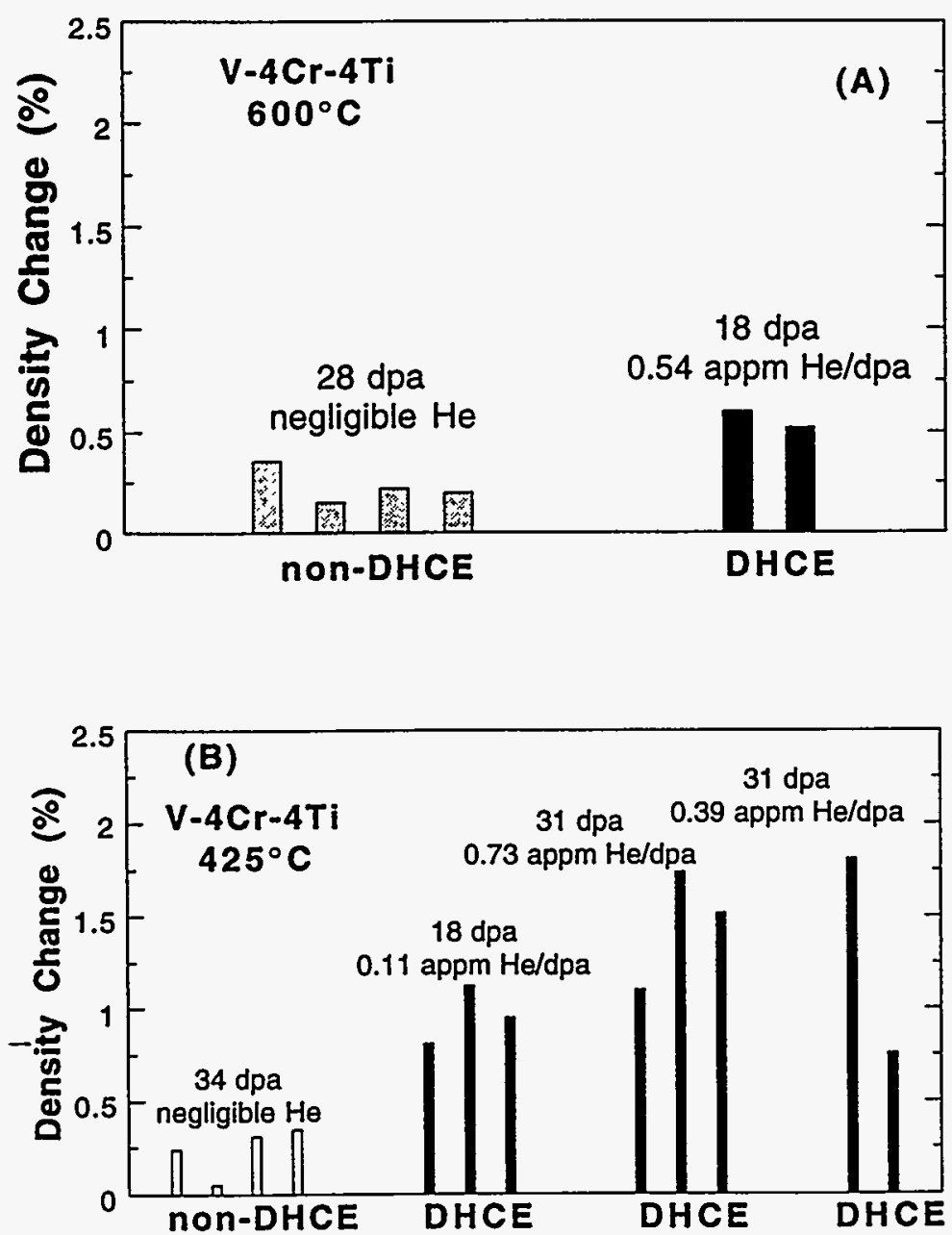

Figure 3. Comparison of density changes of $V-$ - $4 C r-4 T i$ from $D H C E$ and non-DHCE experiments: $(A) 600^{\circ} \mathrm{C}$ and $(B) 425^{\circ} \mathrm{C}$.

\section{DISCUSSION}

Microvolds or helium bubbles were absent from all of the specimens of $\mathrm{V}-4 \mathrm{Cr}-4 \mathrm{TI}$ 
Irradiated in the $\mathrm{DHCE}$ at $500-600^{\circ} \mathrm{C}$, except for a few helium bubbles at interfaces between the grain matrix and some $\mathrm{Ti}(\mathrm{O}, \mathrm{N}, \mathrm{C})$ precipitates that are normally present in V$\mathrm{Ti}$ and $\mathrm{V}-\mathrm{Cr}-\mathrm{Tl}$ alloys. Preferential formation of voids near blocky precipitates Ipresumably $\mathrm{Ti}(\mathrm{O}, \mathrm{N}, \mathrm{C})$ precipitates] was reported by Braski in V-3Ti-1Si specimens that were preimplanted with 82 appm hellum by the tritium-trick technique and then irradiated to $40 \mathrm{dpa}$ at $600^{\circ} \mathrm{C}[8]$.
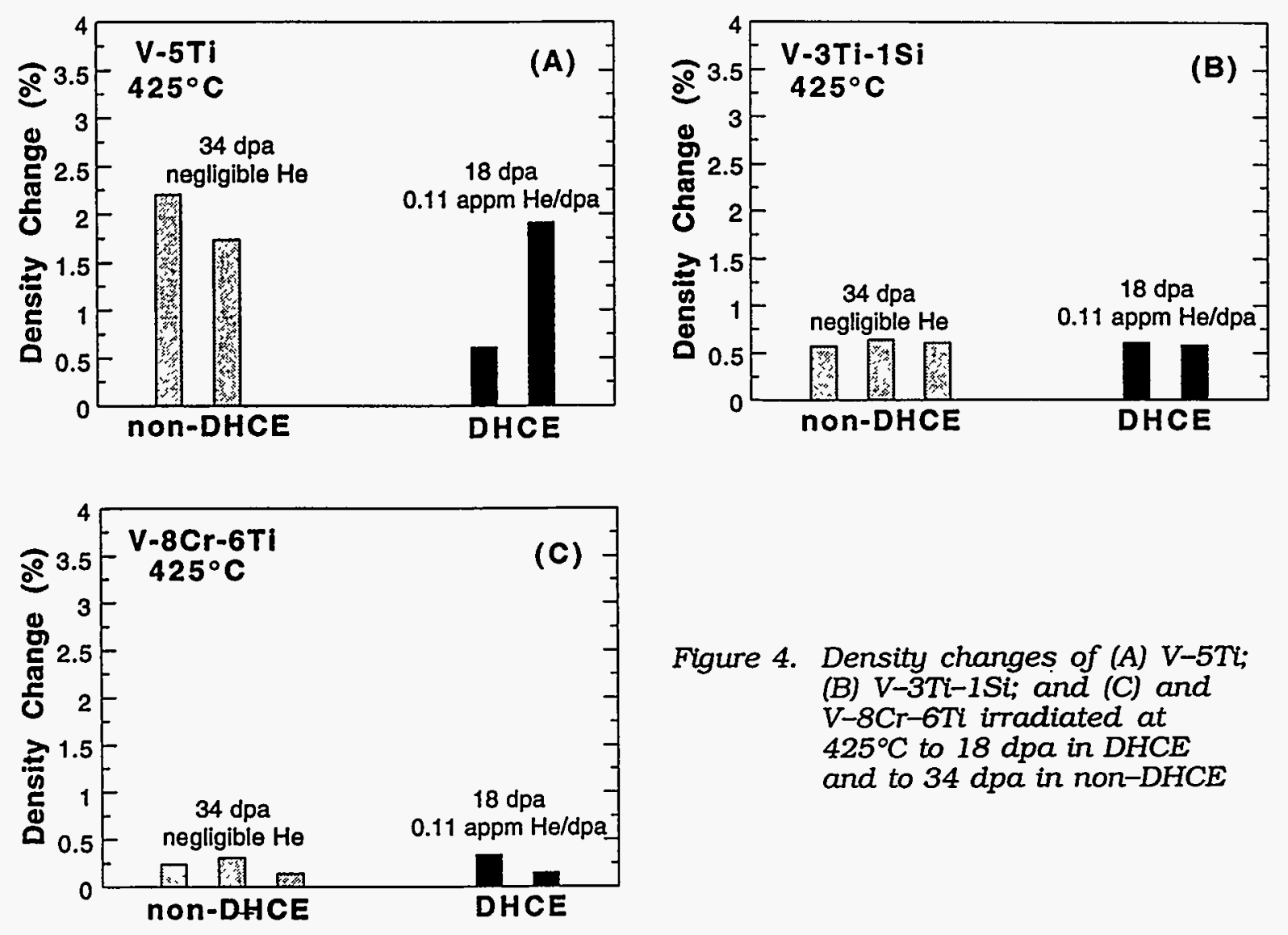

Figure 4. Density changes of (A) V-5Ti;

(B) V-3Ti-1Si; and (C) and $V-8 C r-6 T i$ irradiated at $425^{\circ} \mathrm{C}$ to $18 \mathrm{dpa}$ in $\mathrm{DHCE}$ and to 34 dpa in non-DHCE

Buitenhuis et al. also proposed that interfaces between the grain matrix and $\operatorname{Ti}(\mathrm{O}, \mathrm{N}, \mathrm{C})$ precipitates act as preferential sinks for helium [28]. From a series of thermal desorption analyse by mass spectroscopy, these authors have identified a helium desorption peak at the surprisingly low temperature of $\approx 280^{\circ} \mathrm{C}$ in $\mathrm{V}-5 \mathrm{Ti}$ specimens that were irradiated and implanted with helium lons. Some of the desorption peaks were sharp and narrow and some were weak and broad below and above $\approx 280^{\circ} \mathrm{C}$. Furthermore, Buitenhuis et al. attributed the former and the latter types of peaks to helium-vacancy-impurity $(O, N$, and C) complexes that are produced in the grain matrix and near the interfaces between the 
grain matrix and TI(O,N,C) precipitates, respectively, and are subsequently dissociated into helium and vacancy-impurity complexes upon heating to $\approx 280^{\circ} \mathrm{C}$ or higher. During our degassing treatment in which $\mathrm{DHCE}$ specimens were heated to $\approx 405^{\circ} \mathrm{C}$ at a linear rate of $0.2^{\circ} \mathrm{C} / \mathrm{s}$ in high vacuo in the present study, desorption peaks were observed consistently at $\approx 280^{\circ} \mathrm{C}$. However, a positive identification of helium desorption was not made from a mass spectroscopic analysis.

One of the important findings from the DHCE was that the actual (measured) helium and tritium content of $\mathrm{V}-4 \mathrm{Cr}-4 \mathrm{Ti}$ specimens was significantly lower than that which was calculated on the basis of the assumed equilibrium ratio $\left(\mathrm{k}_{\mathrm{w}}=0.01\right)$ of tritium in the alloy to that in the liquid lithium (Table 2). This could be interpreted to indicate that $\mathrm{k}_{\mathrm{w}}$ is significantly lower than previously thought, in particular for irradiations at 425 and $500^{\circ} \mathrm{C}$.

Microvolds or helium bubbles were absent in the grain matrix and on grain boundaries In all of the specimens irradiated at $500-600^{\circ} \mathrm{C}$, in which ultrafine $\mathrm{Ti}_{5} \mathrm{Si}_{3}$ precipitated in high density. Even in specimens irradiated at $600^{\circ} \mathrm{C}$ at the highest helium generation rate of $\approx 4.2$ appm helium/dpa (Capsule 5C2), no microvoids could be detected either in the grain matrix or on grain boundaries. This correlation between the high-density precipitation of ultrafine $\mathrm{Ti}_{5} \mathrm{Si}_{3}$ and negligible vold swelling seems to be consistent with similar observations reported previously for non-DHCE conditions [27]. Conversely, the relatively higher void swelling and larger density change observed in specimens irradiated at $425^{\circ} \mathrm{C}$ (in Capsule $4 \mathrm{D} 1$ and $4 \mathrm{D} 2$ ) seems to be associated with an absence of precipitation of ultrafine $\mathrm{Ti}_{5} \mathrm{Si}_{3}$ at the low irradiation temperature.

As pointed oūt above, the characteristics of grain-boundary helium bubbles, observed in the specimens irradiated to $31 \mathrm{dpa}$ at $425^{\circ} \mathrm{C}$, were in distinct contrast to those observed in specimens from tritium-trick experiments, i.e., diffuse bubbles in significantly lower number density than those of the compact coalescences of helium bubbles in tritium-trick experiments; discontinous (on $\approx 15 \%$ of grain boundaries), in contrast to continuous ( $\approx 100 \%$ of grain boundaries) colaescences in tritium-trick experiments; and similar bubble distribution in the grain matrix and near grain boundaries, in contrast to virtual concentration of all helium bubbles on grain boundaries in tritium-trick experiments. These characteristics seem to indicate that most of the helium atoms produced at $425^{\circ} \mathrm{C}$ in DHCEs were trapped by vacancies or vacancy-impurity complexes, a finding that is in 
accordance with the findings of Buitenhuis et al. [28].

Intergranular fracture morphology was not observed in any of the specimens irradiated in the DHCE and subsequently tested by uniaxial tensile tests at 23 to $600^{\circ} \mathrm{C}$ and multiple bending tests at -196 to $50^{\circ} \mathrm{C}$ [25]. Even in specimens irradiated at $425^{\circ} \mathrm{C}$ and fractured in brittle manner during multiple bending tests at $-196^{\circ}$. only cleavage and ductile tearing were observed, i.e., intergranular fracture morphology was absent. These observations, consistent with the characteristics of helium bubble distribution described above, are in distinct contrast to the propensity to intergranular fracture that is commonly observed in tritium-trick experiments.

\section{CONCLUSIONS}

1. For specimens irradiated to $\approx 18 \mathrm{dpa}$ at $500-600^{\circ} \mathrm{C}$ in the Dynamic Helium Charging Experiment (DHCE) with helium generation rates of $\approx 0.4-4.2 \mathrm{appm} \mathrm{He} / \mathrm{dpa}$, vold swelling was negligible, and density changes from the DHCE and non-DHCE (negligible helium generation) were similar $(<0.6 \%)$. Only limited number of voids or helium bubbles were observed at the interface of the grain matrix and some of the TI(O,N,C) precipitates. Neither helium bubbles nor voids were observed either in the grain matrix or near grain boundaries. Under irradiation at these temperatures ultrafine $\mathrm{Ti}_{5} \mathrm{Si}_{3}$ precipitated in high density, and most of the dynamically produced helium atoms seem to be trapped in the grain matrix and at the interface between the matrix and $\mathrm{Ti}_{5} \mathrm{Si}_{3}$ precipitates, without a significant chance for bubble nucleation or growth.

2. For DHCE specimens irradiated to $31 \mathrm{dpa}$ at $425^{\circ} \mathrm{C}$ at helium generation rates of $\approx 0.4-$ 0.73 appm He/dpa, helium bubbles $\approx 5 \mathrm{~nm}$ in diameter were observed in localized regions of the grain matrix as well as on limited portions $(\approx 15 \%)$ of grain boundaries. Grain-boundary helium bubbles in these specimens were diffuse, in contrast to the compact coalescences of helium bubbles observed from tritium-trick experiments; discontinous (near $\approx 15 \%$ of grain boundaries), in contrast to continuous (on $\approx 100 \%$ grain boundaries) coalescence observed in tritium-trick experiments; and more or less evenly distributed in the grain matrix and near grain boundaries, in contrast to virtual concentration of all helium bubbles on grain boundaries in tritium-trick 
experiments. These observations indicate that most of the helium atoms that were produced dynamically at $425^{\circ} \mathrm{C}$ were trapped in the grain matrix, preventing formation of continuous coalescence of compact bubbles on grain boundaries. As in non-DHCE, the irradiation-induced prectpitation of ultrafine $\mathrm{Ti}_{5} \mathrm{Si}_{3}$ was not observed after irradiation at $425^{\circ} \mathrm{C}$.

(3) Intergranular fracture morphology was not observed in any of the specimens irradiated in DHCEs and subsequently fractured during uniaxial tensile tests at 23 to $600^{\circ} \mathrm{C}$ and multiple bending tests at -196 to $50^{\circ} \mathrm{C}$. This observation, consistent with the characteristic helium bubble distribution, is in distinct contrast to the propensity to intergranular fracture commonly observed in tritium-trick experiments.

(4) The actual measured helium and tritium content of $\mathrm{V}-4 \mathrm{Cr}-4 \mathrm{Ti}$ was significantly lower than that calculated with an assumed equilibrium ratio $(\approx 0.01$ by weight) of tritium in the alloy to that in the liquid lithium. This indicates that the tritium equilibrium ratio is significantly lower than previously assumed, in particular, for irradiations at $<500^{\circ} \mathrm{C}$. It also indicates that the tritium level in lithium-cooled $\mathrm{V}-4 \mathrm{Cr}-4 \mathrm{TI}$ first wall/blanket structures, and hence the effect of tritium on the fracture toughness, will be significantly lower than previously thought.

\section{ACKNOWLEDGMENTS}

The successful completion of the complex and difficult Dynamic Helium Charging Experiment was possible through many years of contributions from F. W. Wiffen, H. Matsui, K. Abe, C. E. Johnson, R. G. Clemmer, J. P. Kopasz, L. R. Greenwood, M. L. Hamilton, K. L. Pearce, R. Ermi, A. Ermi, H.-C. Tsai, R. V. Strain, J. Gazda, and L. J. Nowicki. The authors are grateful to L. R. Greenwood and B. M. Oliver for calculation and measurement, respectively, of helium and tritium contents.

\section{REFERENCES}

[1] B. A. Loomis, L. Nowicki, and D. L. Smith, "Effect of Neutron Irradiation on Tensile Properties of V-Cr-Ti Alloys," in Fusion Reactor Materials, Semiannual. Prog. Report, DOE/ER-0313/15, Oak Ridge National Laboratory, Oak Ridge, TN (1994), pp. 219222.

[2] B. A. Loomis, H. M. Chung, L. Nowicki, and D. L. Smith, "Effects of Neutron Irradiation and Hydrogen on Ductile-Brittle Transition Temperatures of $\mathrm{V}-\mathrm{Cr}-\mathrm{Ti}$ Alloys," ibid., pp. 253-257. 
[3] H. M. Chung, B. A. Loomis, L. Nowicki, J. Gazda, and D. L. Smith. "Irradiation-Induced Density Change and Microstructural Evolution of Vanadium-Base Alloys," ibid., pp. 223-231.

[4] H. Matsui, M. Tanno, J. Gazda, and H. M. Chung, "Microstructural Stability of V-4Cr4Ti During Neutron Irradiation," ibid., pp. 240-246.

[5] H. M. Chung, J. Gazda, L. Nowicki, J. E. Sanecki, and D. L. Smith, "Effects of Fabrication Variables on Impact Properties and Microstructure of V-Cr-Ti Alloys," ibid., pp. 207-218.

[6] H. M. Chung, B. A. Loomis, and D. L. Smith, "Thermal Creep Behavior of V-5Cr-5TI and V-10Cr-5Ti Alloys," in Fusion Reactor Materials. Semiannual. Prog. Report, DOE/ER0313/14, Oak Ridge National Laboratory, Oak Ridge, TN (1993), pp. 309-317.

[7] D. N. Braskd and D. W. Ramey, in Effects of Radiation on Material Properties, ASTMSTP 870, F. A. Garner and J. S. Perrin, Eds., American Society for Testing and Materfals, Philadelphia, 1985, pp. 1211-1224.

[8] D. N. Braski, in Influence of Radiation on Material Properties, ASTM-STP 956, F. A. Garner, C. H. Henager, and N. Igata, Eds., American Society for Testing and Materials, Philadelphia, 1987, pp. 271-290.

[9] D. N. Braski, J. Nucl. Mater. 141-143 (1986) 1125.

[10] D. N. Braski, in Reduced Activation Materials for Fusion Reactors, ASTM-STP 1047, Philadelphia (1988) pp. 161-178.

[11] H. Matsui, M. Tanaka, M. Yamamoto, and M. Tada, J. Nucl. Mater. 191-194 (1992) 919.

[12] M. Satou, K. Abe, and H. Matsui, J. Nucl. Mater. 191-194 (1992) 938.

[13] M. Tanaka and H. Matsui, Mater. Trans., JIM, 34 (1993) 1083.

[14] W. van Witzenburg, A. Mastenbroek, and J. D. Ellen, J. Nucl. Mater. 103-104 (1981) 1187.

[15] M. P. Tanaka, E. E. Bloom, and J. A. Horak, J. Nucl. Mater. 114 (1981) 895.

[16] M. L. Grossbeck and J. A. Horak, in Influence of Radiation on Material Properties, ASTM-STP 956, Philadelphia (1986) 291.

[17] J. M. Vitek, D. N. Braski, and J. A. Horak, J. Nucl. Mater. 141-143 (1986) 982.

[18] W. van Witzenburg and E. de Vries, in Effects of Radiation on Materials, ASTM-STP 1125. Philadelphia (1990).

[19] L. L. Horton and K. Farrell, J. Nucl. Mater. 122-123 (1984) 687.

[20] H. Kawanishi and S. Ishino, in Reduced Activation Materials for Fusion Reactors, ASTM-STP 1047, Philadelphia (1988) pp. 179-189.

[2 1] H. Kawanishi, Y. Arai, and S. Ishino, J. Nucl. Mater. 191-194 (1992) 933.

[22] D. L. Smith, H. Matsui, L. R. Greenwood, and B. A. Loomis, J. Nucl. Mater. 155-157 (1988) 1359.

[23] D. L. Smith, B. A. Loomis, H. Matsui, M. L. Hamilton, K. L. Pearce, J. P. Kopasz, C. E. Johnson, R. G. Clemmer, and L. R. Greenwood, in Fusion Reactor Materials, Semiannual. Prog. Report. DOE/ER-0313/10, Oak Ridge National Laboratory, Oak Ridge, TN (1991), p. 159.

[24] H. Tsai, H. M. Chung, B. A. Loomis, and D. L. Smith, "Status of Dynamic Helium Charging Experiment (DHCE), in Fusion Reactor Materials, Semiannual. Prog. Report. DOE/ER-0313/15, Oak Ridge National Laboratory, Oak Ridge, TN (1994), p. 247.

[25] H. M. Chung, B. A. Loomis, and D. L. Smith, "Effect of Dynamically Charged Helium on Mechanical Properties of Vanadium-Base Alloys, in this proceeding.

[26] M. Satou and H. M. Chung, in Fusion Reactor Materials, Semiannual. Prog. Rep. 
DOE/ER-0313/13, Oak Ridge National Laboratory, Oak Ridge, TN (1993), p. 227.

[27] H. M. Chung, B. A. Loomis, and D. L. Smith, in Effects of Radiation on Materials, ASTM-STP 1175, A. S. Kumar, D. S. Gelles, R. K. Nanstad, and T. A. Little, Eds., American Society for Testing and Materials, Philadelphia, 1993, pp. 1185-1200.

[28] T. Buitenhuis, A. Fedorov, and A. van Veen, "Thermal Desorption Investigation of V5T1 Alloy," IRI-131-94-005, Delft University of Technology Report, The Netherlands, 1994. 